\title{
Analysis of the mechanical behaviour of the cement mortars with additives of mineral wool fibres from recycling of CDW
}

\author{
Carolina Piña Ramírez ${ }^{\mathrm{a}, *}$, Mercedes del Río Merino ${ }^{\mathrm{a}}$, Carmen Viñas Arrebola ${ }^{\mathrm{b}}$, \\ Alejandra Vidales Barriguete ${ }^{\mathrm{b}}$, Marta Kosior-Kazberuk ${ }^{\mathrm{c}}$ \\ ${ }^{a}$ Polytechnic University of Madrid, Superior Technical School of Building, Department of Architectural Constructions and their Control, Spain \\ ${ }^{\mathrm{b}}$ Polytechnic University of Madrid, Superior Technical School of Building, Department of Building Technology, Spain \\ ${ }^{c}$ Department of Building Structures and Architecture, Faculty of Civil and Environmental Engineering, Bialystok University of Technology, Poland
}

- Waste mineral fibres are an alternative to current commercial reinforcements.

- Mortars reinforced with mineral fibers waste minimize environmental impact.

- There is a good connection between the cementitious matrix and the residues.

- It is possible to replace large amount of the volume of sand used by mineral fiber waste.

\begin{abstract}
A B S T R A C T
This research analyses the viability of the valuation of mineral wool waste from construction and demolition waste (CDW) as reinforcement of cement matrices. The objective is to analyse the mechanical behaviour of a material composed of a cement mortar matrix to which the aforementioned waste is incorporated. For this purpose, an experimental plan is made in which cement mortar specimens are made with different \% of different types of waste, on which Shore D surface hardness, Module of Young, fracture energy, flexural and compressive strength and microscopy tests are carried out, to evaluate their viability as a reinforcement material. The results of the tests show that although the mechanical resistance decreases there is a good connection between the cementitious matrix and the waste resulting in a sustainable alternative to the fibres used today.
\end{abstract}

\section{Introduction}

Since 1991 construction and demolition waste (CDW) has been recognized by the European Commission as one of the six priority waste streams [1], but it was the current Waste Framework Directive 2008/98 /CE which prioritized the elimination, prevention and reuse of materials $[2,3]$.

In fact, around 850 million tons of CDW are generated each year in Europe [4], and although the trend is decreasing due to the recent economic crisis in the real estate sector, this continues to generate a serious environmental problem as only $50 \%$ of this waste is recycled [5], so it seems difficult to achieve the EU 2020 goal of recycling $70 \%$ of waste materials [1].

\footnotetext{
* Corresponding author: Technical University of Madrid, Avda. Juan de Herrera, 6 28040 Madrid, Spain.

E-mail address: carolina.pina@upm.es (C. Piña Ramírez).
}

As a result, the use of waste to replace part of the raw material of construction materials has become an attractive solution for recycling and the revaluation of CDW in recent decades [6,7]. In this research it is proposed to reduce the aggregate used for the production of cement mortars by waste to the maximum, as sand is the most demanded natural resource in the world, followed by water and ahead of fossil fuels [8].

In particular, mineral wool waste from the insulation of homes has increased in recent years due to the increment in thermal and acoustic requirements set by the current regulations for energy saving [9]. Up to $0.2 \%$ of the volume of all CDW generated are mineral wool [10], accounting for $60 \%$ of the insulating materials used in construction. It is also estimated that in 2020 , more than 2.5 million mineral wool waste will be generated in the EU-28 zone, characterized by its difficult reuse, low recycling rate and forms of recovery [11].

Therefore, it could be considered that the recycling of these mineral wool waste might be an interesting alternative to the rein- 
Table 1

Composition of compounds.

\begin{tabular}{lllll}
\hline Name & Cement $(\%)$ & Sand $(\%)$ & Water $(\%)$ & Fibre $(\%)$ \\
\hline Reference & 33.33 & 100.00 & 20.00 & 0.00 \\
$30 \%$ RW & 33.33 & 70.00 & 20.00 & 30.00 \\
$30 \%$ FG & 33.33 & 70.00 & 20.00 & 30.00 \\
$30 \%$ MIX & 33.33 & 70.00 & 20.00 & 30.00 \\
\hline
\end{tabular}

forcement fibres that are currently used and thus manufacture more eco-efficient materials, also seeking to improve their mechanical properties and avoid its disposal [12].

The cement matrix is basically a material composed of calcium hydroxide (portlandite), aluminates and non-hydrated cement (clinker), dissolved in a nanostructured amorphous hydration product called C-S-H gel (calcium silicate hydrate) [13] which is responsible for the good mechanical properties of the cement paste [14].

It is known that cement-based materials are characterized by a weakness, caused by their greater rigidity, when subjected to problematic tensile or flexural stresses [15] which has been tried to be solved with the addition of fibres.

On the other hand, today the mortars reinforced with fibres present the problem of lacking specific regulations, so the point is to assimilate to the rules of unreinforced mortars. The drawback it presents is that the mechanical behaviour is markedly not linear since the fibres begin to work after the cracking of the cement mortar matrix [16].

At present the most used fibres in cement mortars are polymer fibres [17-19], steel fibres [20] and AR glass fibres (alkali resistant) $[21,22]$, but this seems to be an unsustainable option and a large amount of energy is needed in manufacturing using fibres like the ones of previous studies.

Numerous studies have been found on the reinforcement of cement mortars with mineral fibres, both rock wool $[23,24]$ as well as fiberglass, [25] in which their influence on the mechanical properties [26] and on the toughness of composite materials is checked.

The results of the studies carried out on cement mortars reinforced with fibres indicate that in the majority of the cases the resulting mortars show a decrease in the compressive strength of around $14 \%$ for the polymeric fibres [18], 3\% for metallic fibres [27] and 20\% for glass fibres [25] flexural strength increases by about $25 \%$ for polymer fibres [18,28], $12 \%$ for metallic fibres and $15 \%$ for glass fibres [29].

We have also found works that analyse the characterization of cement mortars reinforced by additions of other waste such as glass powder [30] or polyethylene waste [31], in which there is a decrease in its bulk density causing a reduction of its mechanical properties.

Reinforcement studies have also been found with similar waste of mineral wool, but in other matrices such as plaster [32] or in polypropylene [33].

On the other hand, no research has been found that analyses the incorporation of different types of architectural waste of mineral wool [34] in cement mortars. In this context, it is considered a matter of great importance to study the feasibility of using fibres from recycling for its reinforcement from the point of view of the influence of the physical and mechanical properties of cement mortars and thus be able to provide an ecological alternative to the fibres used today and also reduce the CDW generated by the construction industry.

Therefore, in this article we proceed to the physical and mechanical analysis of the mortars made with three different types of mineral wool waste, in order to discern if these can be an alternative to the less sustainable traditional mortars; with two main objectives: first of all, to add the maximum amount of fibre for recycling, and secondly, to obtain mechanical strengths required similar to those achieved for cement matrix with commercial fibres.

\section{Materials and methods}

\subsection{Materials}

The materials used in this work were cement Portland Cem II/B-L $32.5 \mathrm{~N}$ (supplied by the company Cementos Portland Valderrivas, Madrid, Spain), river sand with a diameter of $4 \mathrm{~mm}$, water and three different types of mineral wool waste: fiberglass waste, rock wool waste and mixed waste of mineral wool.

The water used came from the Canal de Isabel II of Madrid that has the technical characteristics established in the standard UNE EN 13279-2.

The mineral wool waste used in the study came from the Centre for the Integra Treatment of Construction and Demolition Waste (CDW) located in El Molar (Madrid, Spain), and managed by the company Gedesma SA. The fibres are stored in the open-air dump, mixed with other waste, and had been collected and separated from them for this work through a manual process. Subsequently, the rock wool and fiberglass wool waste were separated and constitute the samples called RW and FG respectively. A third sample formed by a mixture of rock wool and fiberglass as it was found in the landfill was separated and is called MIX in this study (Fig. 1). The three types of mineral fibre waste have been subjected to a previous treatment by grinding them in the machine model Cutting Mill Retsch M 100 of $1.5 \mathrm{~kW}$ motor and a rotor speed of $1500 \mathrm{rpm}$, for 3 intervals of 3 min each, resulting in a fibre format of between $500 \mu \mathrm{m}$ and $1000 \mu \mathrm{m}$ in length, which is thought to be suitable for incorporation into the cement matrix. This is due to the fact that in the consulted bibliography the normal size of the mineral fibres used for this purpose is usually $12 \mathrm{~mm},[21,25,35]$ but in smaller quantity than in this investigation, so it is thought that having a smaller size fibre-matrix connection will be more convenient.

Following the indications of the standards UNE EN1015-2:2012 and UNE EN1015-11:2000, the series of prismatic test pieces of dimensions $4 \times 4 \times 16 \mathrm{~cm}$ with dosage 1:3:0.6 (cement: sand: water) incorporating the three types of fibre waste in the following percentages, replacing in volume part of the aggregate: $30 \%, 40 \%$ and up to $50 \%$, since it was found that from $50 \%$ the mortars were not workable (Table 1 ).

For manufacturing the mortars, the additions of fibres in the water are first incorporated and then the cement is added and the manual kneading is carried out for $15 \mathrm{~s}$. Subsequently, the mixer is started, which mixes the components at a slow speed for $15 \mathrm{~s}$, and then incorporates the aggregate, making a rapid kneading for $75 \mathrm{~s}$. Once the elaboration process is finished, the flow table consistency of each of the mixtures is determined by measuring the pour value specified in the standard UNE EN-1015-3 (Fig. 2).

After $24 \mathrm{~h}$ of curing in a humid chamber at a temperature of $20^{\circ} \mathrm{C}$ and a relative humidity of $95 \%$, the samples are removed from the moulds, and they are introduced again into the humid chamber where they remain for a total of 28 days until they reach the necessary hardness to be submitted to the different tests.

\subsection{Experimental plan}

An experimental plan was designed in 3 phases in the materials laboratories of the Higher Technical School of Building, in the chemistry of the Higher Technical School of Engineering and Industrial Design, both belonging to the Polytechnic University of Madrid, and in the structure laboratories of the Faculty of Civil and Environmental Engineering, Bialystok University of Technology.

Prior to the study, a complete characterization of both the raw materials of the compounds and the three types of mineral wool waste used (rock wool_RW, fiberglass_FG, fibre mixture_MIX) was carried out by physical-chemical tests (X-ray fluorescence, X-ray diffraction (XRD), differential thermal and thermal gravimetric analysis (DTA/TGA), scanning electron microscopy (Fig. 3), and bulk density), to check their viability [36].

Different percentages of incorporation of the waste have been experimented to study the evolution of the composite material as the content of fibre waste increases.

2.2.1. Phase 1: Mechanical tests of mortars with additions of fibres

The Shore D surface hardness, flexural and compressive strength of the compounds tests were carried out with additions of $30 \%, 40 \%$ and up to $50 \%$ of fibre waste.

Shore D surface hardness (UNE-EN 102042): a meter measuring the Shore D surface hardness was used on the two lateral longitudinal sides of the test pieces.

Flexural and compressive strength (UNE-EN 1015-11): the Autotest 200 work unit from Ibertest was used, and a load was applied at progressive and constant speed until the break, and the obtained value was recorded.

2.2.1.1. Phase 2: Mechanical tests of selected mortars. In order to carry out a more detailed analysis, the Module of Young, fracture energy tests were carried out of the selected mortars.

Module of Young (UNE EN 12390-13): with machinery of the company CONTROLS the test allowed to determine the stabilized elasticity modulus measured after three load cycles (Fig. 4). 

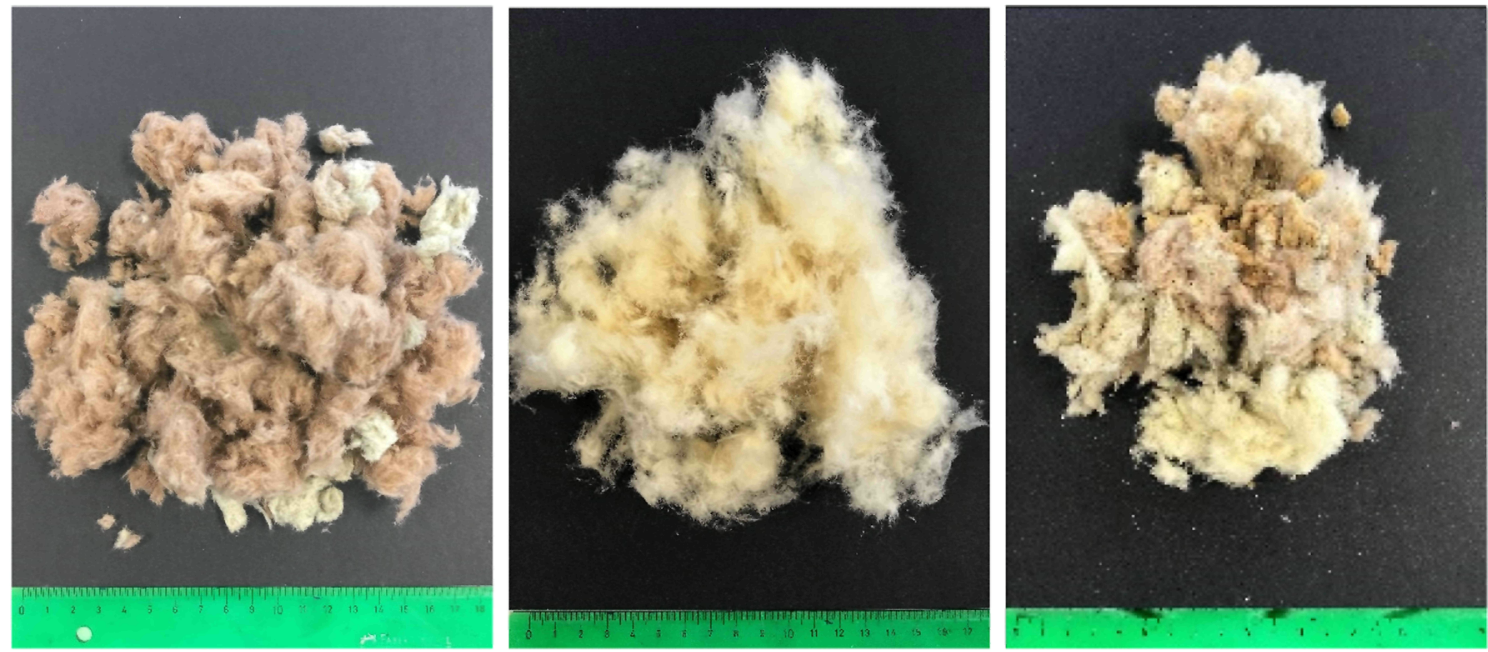

Fig. 1. Waste transformed from left to right: rock wool waste (RW), fiberglass waste (FG) and mixed waste of mineral wool (MIX).
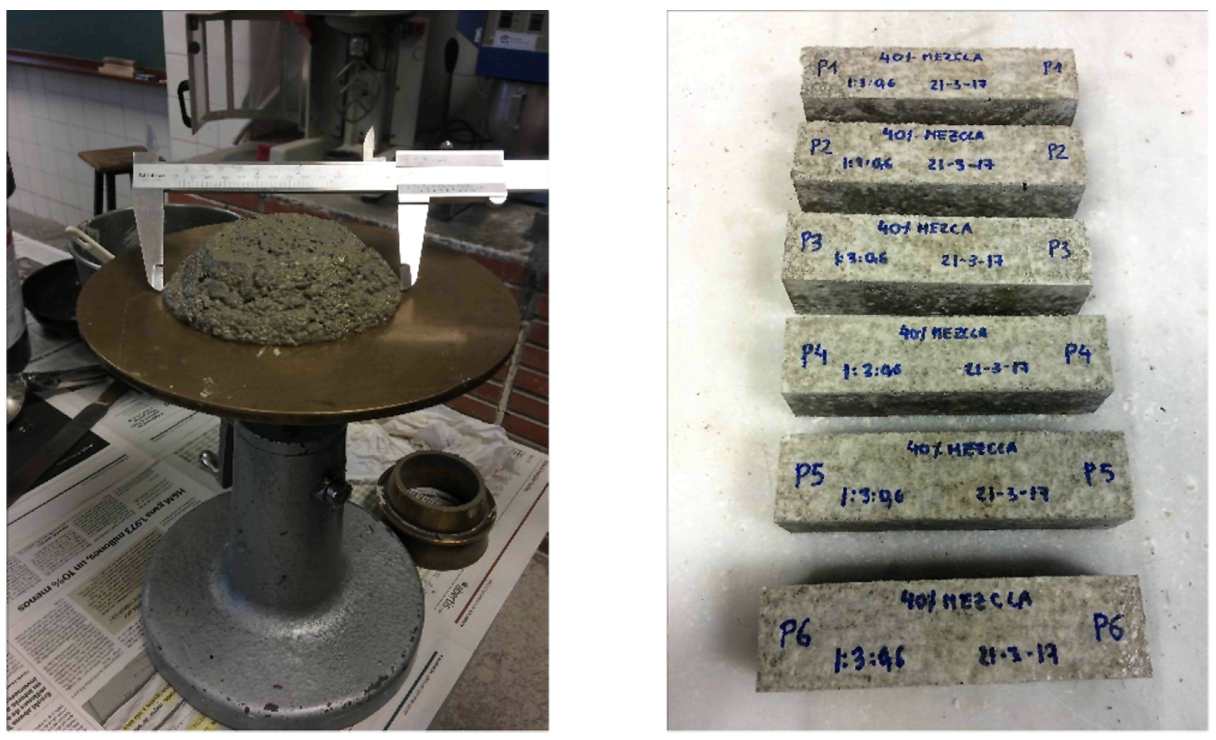

Fig. 2. From left to right: consistency test and test pieces performed.
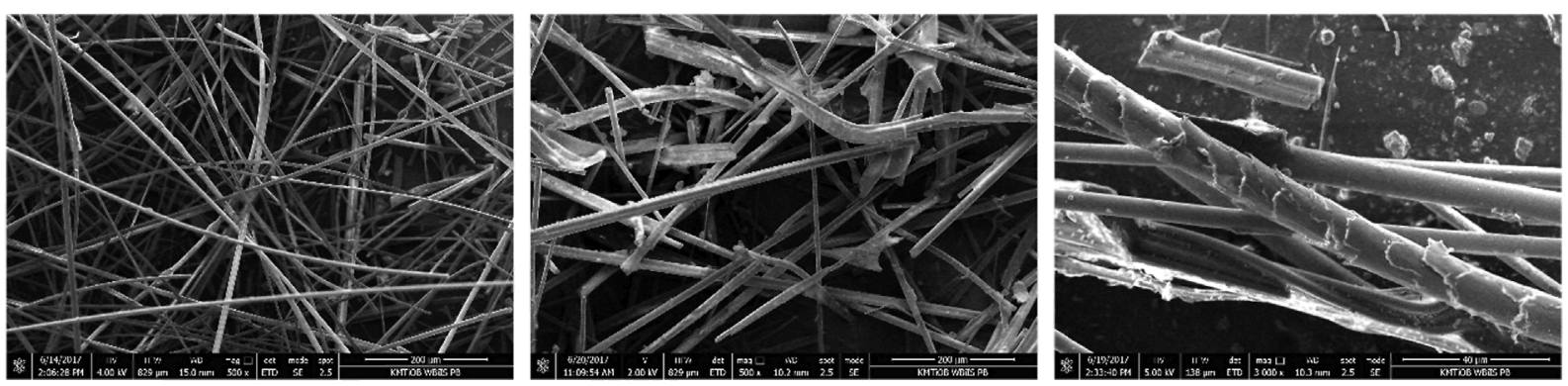

Fig. 3. SEM micrographs for fibres: (a) RW, (b) FG, (c) MIX).

Fracture energy (UNE EN-14651 A1:2008): using the Zwick/Roell Z250 device from the company CONTROLS, the proportionality limit (LOP) was determined, as well as the residual tensile strength due to bending and the area under the load-deformation curve per fractional surface unit called fracture energy (GF) (Fig. 5)
2.2.1.2. Phase 3: Microscopy of selected mortars. The mortar samples were covered by low vacuum (gold) sputter coating with an EMITECH K550X Sputter Coater, at a current of $30 \mathrm{~mA}$ over $2 \mathrm{~min}$, in an Argon atmosphere. Subsequently, the mortar samples were analysed by scanning electronic microscopy Model JEOL JSM-6460-LV with an INCA elemental X-Ray analysis system, at an acceleration voltage of $0.2-30 \mathrm{KV}$ (Fig. 6). 


\section{Results and discussion}

\subsection{Phase 1: Mechanical tests of mortars with additions of fibres}

Below are the results of the tests carried out with the additions of $30 \%, 40 \%$ and $50 \%$ for the three types of waste used.

\subsubsection{Shore D surface hardness}

Regarding the surface hardness of the mortars (Shore D surface hardness), we see in Fig. 7 that depending on the type of mineral fibre residue used, they show a different behaviour compared to this property.

The addition of rock wool waste highly increase cement matrix hardness with the percentage of addition of $40 \%$ compared to $30 \%$, again decreasing when $50 \%$ of addition is reached. It is possible that this non-linear behaviour is due to the fact that rock wool fibres have a higher density than the other analysed fibres $[37,38]$, so they present a less homogeneous connection with the matrix, producing accumulations of fibre on the surface of the test specimen. The surface hardness of the mortars decreases by 4.6 points when incorporating the fiberglass waste, while the values for the compounds with fibre mixture waste remain very similar with the additions of $30 \%, 40 \%$ and $50 \%$. It is observed that the best values are obtained in the mixtures with $40 \%$ for the mineral wool fibre waste, and the lowest values for the $50 \%$ of the fiberglass waste addition.

3.1.1.1. Flexural and compressive strength. Fig. 8 shows the average results obtained in the tests of flexural strength on the ready-made specimens.

From the results obtained in the test it is observed that the flexural strength in general increases significantly by adding mineral fibre waste to the matrix, except for compounds with $40 \%$ and $50 \%$ glass fiber.

It is observed that both for the mortars with rock wool waste additivity, as for those of glass fiber, there is a decrease in the flexural strength in the series with $40 \%$ of the waste compared to those containing $30 \%$ of waste, producing an increase in this resistance for the compounds added with $50 \%$ of waste in all three cases. The lack of homogeneity of the compounds with $40 \%$ addition of rock wool should be noted again, this may be due to a good dispersion of fibres when adding $30 \%$, while with $40 \%$ disorder occurs and accumulation of the same in the surface, whereas with $50 \%$ the great amount of added fibres causes the compound to be homogeneous again.

The values of flexural-tensile strength obtained stand out in the series with $50 \%$ with mixed residues of mineral wools increasing

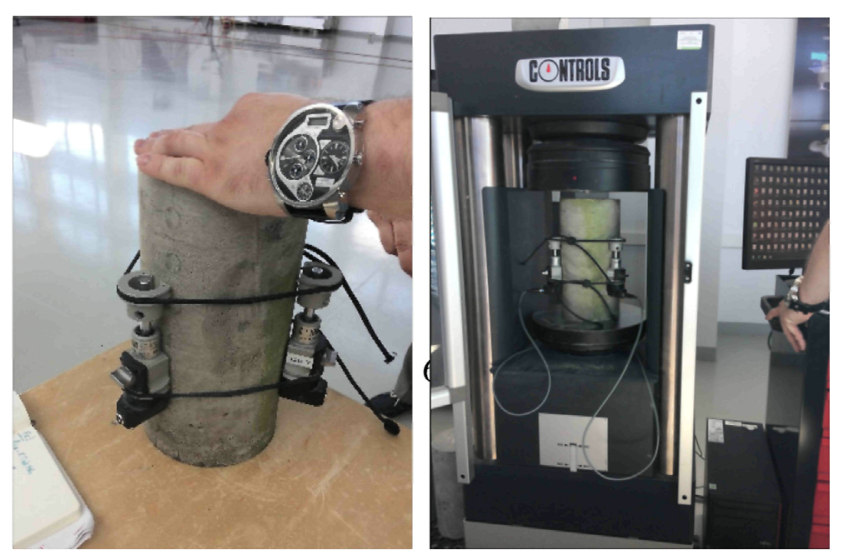

Fig. 4. Module of Young test. up to $12 \%$ (7.33 $\mathrm{MPa}$ ) with respect to the reference, presenting the least resistance (6.36 MPa and $6.46 \mathrm{MPa})$ the series with additions of $40 \%$ and $50 \%$ respectively, with rock wool waste.

Unlike what happens with the tensile and flexural values, these cement-based materials express a worse mechanical performance when it comes to compressive strength.

As expected, the compressive strength decreases compared to the non-reinforced matrix, as it can be seen in Fig. 9, due to an increase in the porosity of the composite material observed in the occluded air test of the mixtures, where they were obtained values of $3.1 \%, 4.6 \%, 9.9 \%$ and $4.8 \%$ for the samples REF, RW, FG and MIX respectively.

The data show that, on average, the compressive values of cement mortars added to fibre waste suffer a reduction in their compressive strength, in all cases, of more than $13 \%$ compared to mortars without the addition of fibre waste.

The values obtained in the test of resistance to compression are lower than the reference, but in all of the percentages exceeds by more than $13 \mathrm{MPa}$ the established by standard UNE-EN 998-1 "Specifications of mortars for masonry".

Compounds with mixed mineral wool waste addition have similar values for the three percentages of addition.

Although they present very similar results, the best performance of the specimens is with the addition of rock wool fibre waste at $30 \%(27.00 \mathrm{MPa})$ and the worst of $50 \%$ glass fibre $(21.42 \mathrm{MPa}$ ) stands out, which means a reduction of this resistance with respect to the matrix by $27.6 \%$, values very close to those of the current commercial mineral fibres.

\subsection{Phase 2: Mechanical tests of selected mortars}

In this phase, the Young's Modulus and fracture energy tests were carried out only the compounds with the additions of $30 \%$ for the three types of waste used, since they were those that presented a better mechanical behaviour on compression and a higher surface hardness on average, although it should be pointed out that this $30 \%$ in substitution of part of the aggregate measured in volume accounts for $2 \%$ in weight for rock wool, $7 \%$ for fiberglass and $4 \%$ for fibre mixture, values above those normally used with commercial fibres $[25,29,39]$.

\subsubsection{Young's modulus}

It is verified that the incorporation of fibre waste reduces the modulus of elasticity of the compounds analysed, for the addition of $30 \%$ of the three types of mineral wool waste used. In the values obtained (Table 2) it was observed that the mortars that incorporate rock wool waste, fiberglass waste and mixed waste of mineral wools, present $16 \%, 20.5 \%, 17.6 \%$ less rigidity that the reference mortar. It is also reflected that the most elastic compound is the mortar to which fiberglass is incorporated.

\subsubsection{Fracture energy}

Table 3 shows the values obtained in the test of fracture energy in which the part of elastic GFel energy and plastic GFpl up to the propagation of cracks related to the total measured energy GF is observed, which gives an idea about the relative and absolute proportion of the elastic part of the fracture energy. The energy demanded for the initiation of cracks increased with the addition of fibres concluding that the elastic and plastic energy parts increased.

The fracture energy was analysed for a complete understanding of the behaviour during destruction in the composite materials test [40]. The load curves $P$ versus deflection $\delta$ are shown in Fig. 10, these were used to determine the total fracture energy (GF). The presence of fibres increased the critical load and the deviation of the samples tested. Considering the shape of the curves, the 

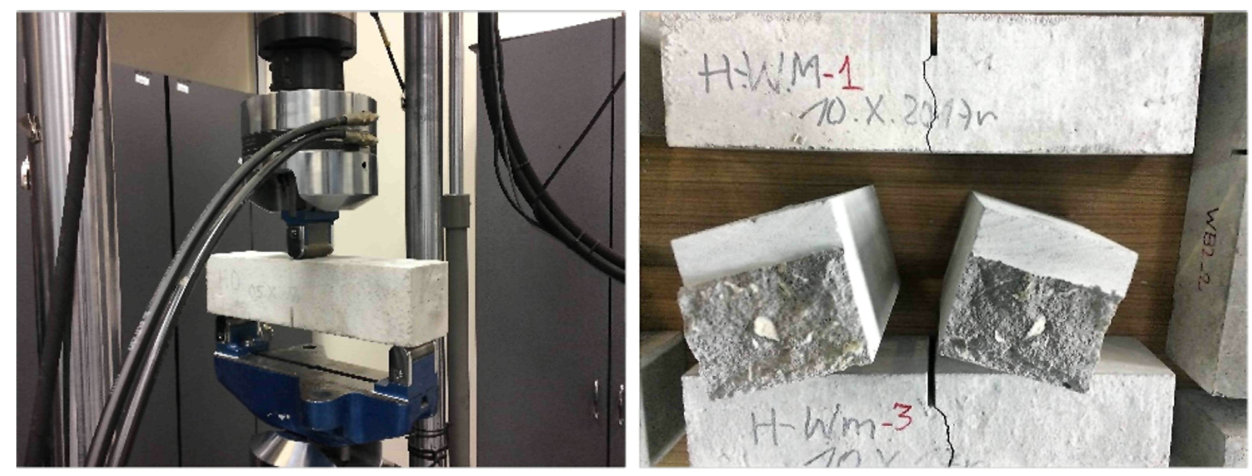

Fig. 5. Fracture energy test.

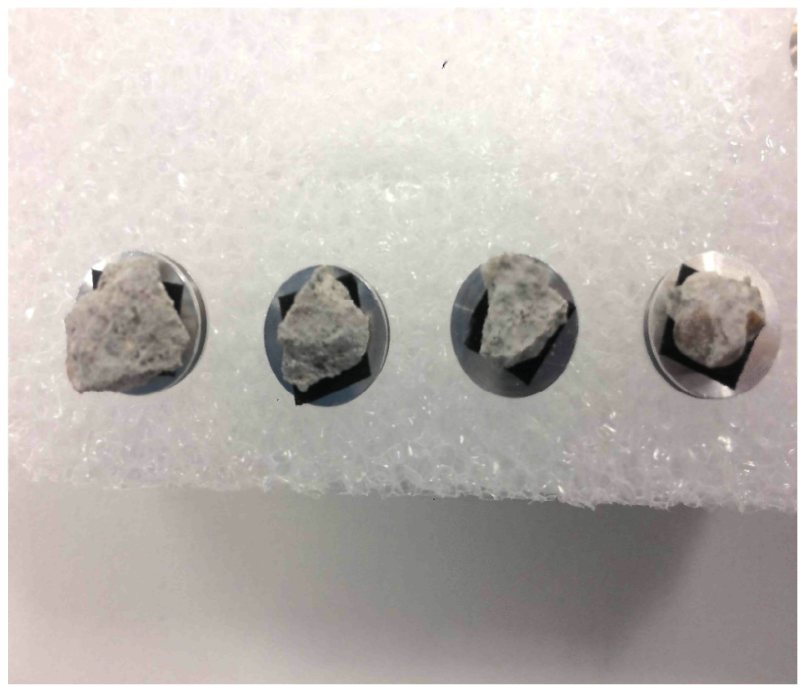

Fig. 6. Mortar samples Microscopy test (SEM).

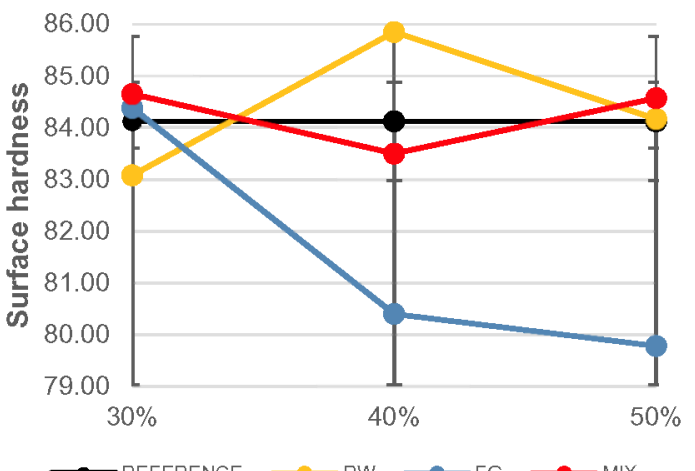

Fig. 7. Shore D surface hardness values in the compounds.

increase in deflection was the smallest for the mortar with fibre mixture, and it was the largest in the case of mortar with fiberglass waste. The highest values of force in the post-critical phase (descending part of the graph) were observed for the mortar with mixed fibres, while for the reference mortar, the post-critical phase was the shortest.

The results obtained from the test, carried out in reinforced mortars with a mixture of fibres, made it possible to analyse the influence of fibre on the fracture properties of the material. The

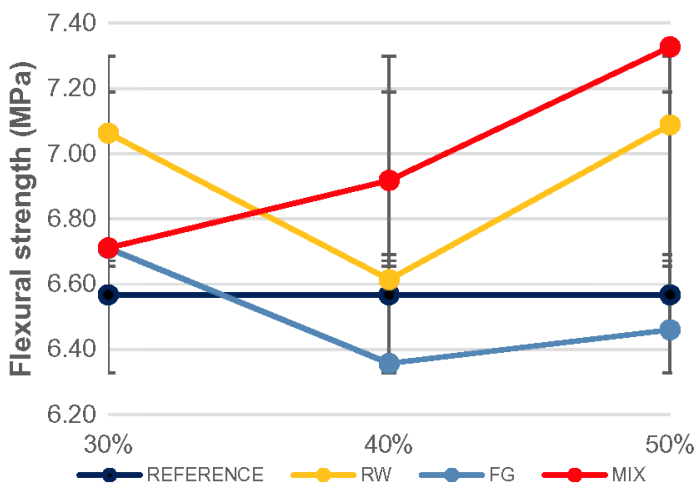

Fig. 8. Values of flexural strength of the compounds (Mpa).

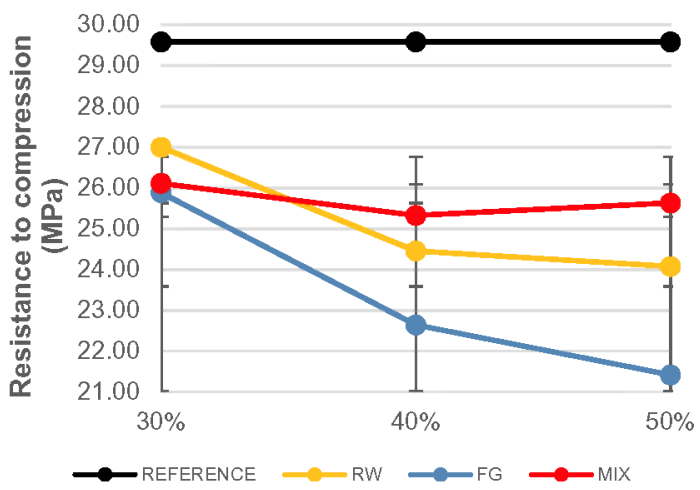

Fig. 9. Values of compressive strength of the compounds (Mpa).

Table 2

Values of the Young's Modulus (MPa).

\begin{tabular}{llll}
\hline Fibre content (\% vol.) & Cycle (MPa) & Young's Mod. & Standard deviation \\
\hline Reference & 22.87 & 22.92 & 0.12 \\
& 22.83 & & \\
$30 \%$ RW & 23.06 & & \\
& 19.30 & 19.23 & 0.11 \\
& 19.29 & & \\
$30 \%$ FG & 19.11 & & 0.02 \\
& 18.20 & 18.22 & \\
$30 \%$ MIX & 18.24 & & 0.01 \\
& 18.22 & & \\
& 18.89 & 18.89 & \\
& 18.88 & & \\
& 18.90 & & \\
\hline
\end{tabular}


Table 3

Elastic and plastic part of the fracture energy GF until crack propagation.

\begin{tabular}{|c|c|c|c|c|c|}
\hline Fibre content (\% vol.) & $\begin{array}{l}G_{F} \\
\left(\mathrm{Nm} / \mathrm{m}^{2}\right)\end{array}$ & $\begin{array}{l}G_{F p l} \\
\left(\mathrm{Nm} / \mathrm{m}^{2}\right)\end{array}$ & $\begin{array}{l}G_{F e l} \\
\left(\mathrm{Nm} / \mathrm{m}^{2}\right)\end{array}$ & $\begin{array}{l}G_{F p l} \\
(\%)\end{array}$ & $\begin{array}{l}G_{F e l} \\
(\%)\end{array}$ \\
\hline Reference & 75 & 5 & 20 & 7 & 27 \\
\hline $30 \%$ RW & 88 & 4 & 38 & 5 & 43 \\
\hline $30 \% \mathrm{FG}$ & 97 & 6 & 34 & 6 & 35 \\
\hline $30 \%$ MIX & 104 & 11 & 28 & 11 & 27 \\
\hline
\end{tabular}

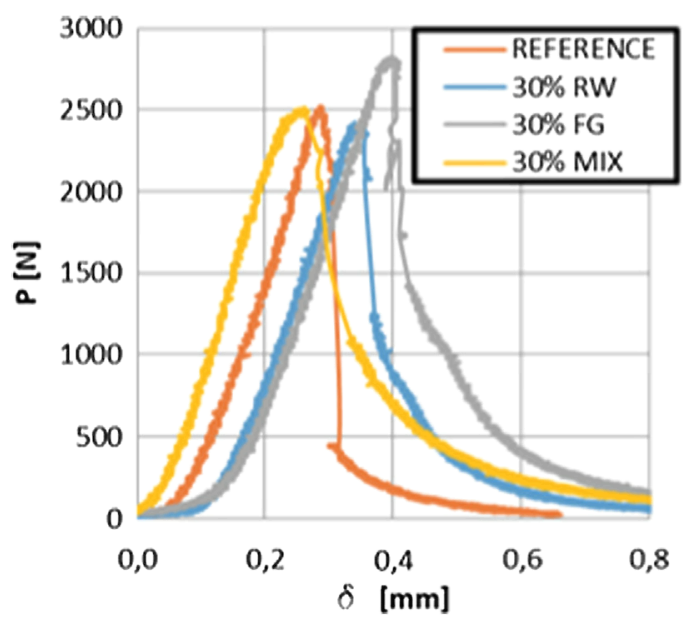

Fig. 10. Load $P$ versus deflection $\delta$ envelopes of concretes with mineral wool fibres residues.

behaviour prior to the peak of the material was slightly affected by the addition of fibres to the cement matrix. At this stage, the deformation regime was dominated by the properties of the cement matrix, but the fibres caused a slight increase or an almost insignificant effect on the maximum load value, however the post-peak behaviour revealed a significant improvement in comparison with the reference mortar without fibres. After the test, the results of the measurement of the toughness and the characteristics of energy absorption showed that the compounds with fibres from mineral wool residues acquire a great ductile behaviour and capacity for energy absorption, in comparison with the samples of the mortar of reference.

The analysis of the P-CMOD diagrams (load- displacement of the edge of the fissure) showed that in reinforced mortars, postpeak fracture behaviour was greatly improved by the addition of mineral wool fibre waste.

\subsection{Phase 3: Microscopy}

Fig. 11 shows the microphotographs of the selected compounds. In the images it can be clearly seen that there is a coherence between the fibres and the base mortar. From these images it can be deduced that the presence of fibres has affected the mortar setting, since it is observed that the mortar mass is set around the fibres without significant additional porosity being produced. Therefore the fibres remain embedded in the set mass, which could indicate a good adhesion between the mortar and the fibres, which is verified in the mechanical behaviour. Although it is also observed that the distribution may not be homogeneous, it is not possible to control the surface properties, which could be solved by the use of additives. Likewise, in all cases the rupture of the filaments is observed almost flush with the matrix, indicating a fragility of the material, similar to the photogrammetry of studies with commercial fibres [25].

The ready-made mortars have a high \% of fibres in substitution of\% of sand measured in volume (30\%), but it should be pointed out that these quantities measured in mass are not high values, so they might not be enough to produce large changes in the microscopic structure of the composite material. However, the glass fibres, being the ones with highest density, present a larger quantity in the composite material, which has led to further deterioration of its mechanical properties.

\section{Conclusions}

From the analysis of the results obtained in the mechanical and microscopic tests carried out, it can be concluded that the use of mineral wool residues as reinforcements in cement-based mortars is a viable alternative to the use of current reinforcing fibres. With their incorporation, we will not only minimize the environmental impact by reducing the use of sand, the most demanded natural resource of the planet, as raw material for its manufacture, but we will also be revaluing this waste that is currently not being recycled.

First of all, with these additive mortars it is possible to replace up to $50 \%$ of the volume of the sand used, which means a large amount of raw material savings and a high-volume recycling of mineral wool.

Secondly, the compounds obtained, although their mechanical resistance to compression reduced, still meet the minimum requirements demanded by current standards, and are to the commercial mineral fibres used today. As to flexural strength, this is enhanced by the incorporation of this type of waste, being in very
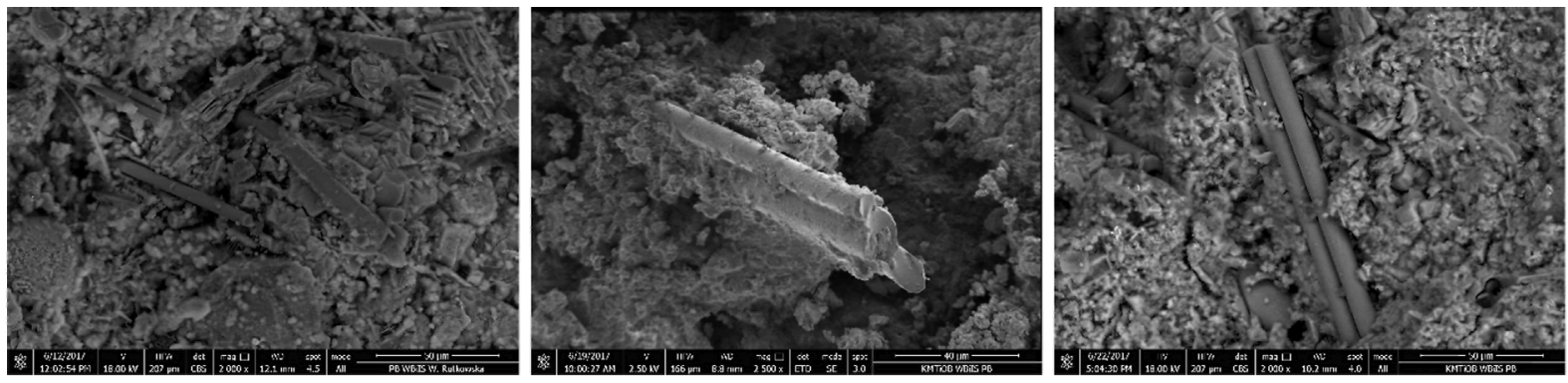

Fig. 11. SEM micrographs for the mortars with additivity of fibres: (a) RW, (b) FG, (c) MIX). 
similar values compared to those that incorporate polymeric fibres and AR glass.

The success of manufacturing materials with mineral wool waste as secondary material will have important implications for the environment, resulting in a useful material characterized by good compatibility of fibres with the cement matrix.

\section{Conflict of interest}

None.

\section{References}

[1] S. Papatzani, K. Paine, Overview of construction and demolition waste legislation in EU and Greece \& state of the art on recycling CDEW in concrete, 2015.

[2] C. Europea, Europa 2020: la estrategia europea de crecimiento, 2012. doi:10.2775/39991.

[3] C. Europea, Cerrar el círculo: un plan de acción de la Comisión al Parlamento Europeo, al Consejo, al Comité Económico y Social Europeo y al, Comité de las Regiones (2015).

[4] N. Pecic, I. Ignjatovic, J. Dragaš, N. Tošic, Long-term behaviour of reinforced beams made with natural or recycled aggregate concrete and high-volume fly ash concrete, 176 (2018) 344-358. doi:10.1016/j.conbuildmat.2018.05.002.

[5] P. Villoria Sáez, M. Del Río Merino, C. Porras-Amores, Estimation of construction and demolition waste volume generation in new residential buildings in Spain, Waste Manag Res. 30 (2012) 137-146, https://oi.org/ $10.1177 / 0734242 \times 11423955$.

[6] M.N. Soutsos, K. Tang, S.G. Millard, Use of recycled demolition aggregate in precast products, phase II: concrete paving blocks, Constr. Build. Mater. 25 (2011) 3131-3143, https://doi.org/10.1016/j.conbuildmat.2010.12.024.

[7] A. Bourguiba, E. Ghorbel, L. Cristofol, W. Dhaoui, Effects of recycled sand on the properties and durability of polymer and cement based mortars, Constr. Build. Mater. 153 (2017) 44-54, https://doi.org/10.1016/j.conbuildmat.2017.07.029.

[8] P. Pascal, Sand, rarer than one thinks Article reproduced from United Nations Environment Programme (UNEP) Global Environmental Alert Service (GEAS), Environ. Dev. 11 (2014) 208-218.

[9] A.M. Papadopoulos, State of the art in thermal insulation materials and aims for future developments, Energy Build. 37 (2005) 77-86, https://doi.org/ 10.1016/j.enbuild.2004.05.006.

[10] O. Väntsi, T. Kärki, Mineral wool waste in Europe: a review of mineral wool waste quantity, quality, and current recycling methods, J. Mater. Cycles Waste Manag. (2014) 62-72.

[11] L. Bertố Carbó, Nuevos materiales, modelos y técnicas de caracterizaciôn en acústica de la edificación y acústica medioambiental, 2015.

[12] X.E. Castells, Tratamiento y valorización energêtica de residuos, Ediciones (2012).

[13] J.J. Gaitero, I. Campillo, A. Guerrero, Reducción de la lixiviaciôn del ión calcio en pasta de cemento mediante adición de nanopartículas de sílice, Cem. y Hormigón. 974 (2016) 28-34.

[14] F. Puertas, Cementos de escorias activadas alcalinamente: Situación actual y perspectivas de futuro, $45,1995,53-64$.

[15] M.L. Mana Halvaei, Masoud Jamshidi, Application of low modulus polymeric fiber's in engineered cementitious composites, J. Ind. Text. 43 (2014) 511-524.

[16] M. Kosior-kazberuk, J. Krassowska, Fracture behaviour of basalt and steel fibre reinforced concrete, Bud. i Inżynieria Środowiska. 6 (2015) 73-80.

[17] H.R. Pakravan, M. Jamshidi, M. Latifi, Investigation on polymeric fibers as reinforcement in cementitious composites: Flexural performance, J. Ind. Text. 42 (2012) 3-18.

[18] F.M. Cebrián, Comportamiento Mecánico del Hormigón Reforzado con Fibra de Polipropileno Multifilamento: Influencia del Porcentaje de Fibra Adicionado, $2011,82$.

[19] F. Puertas, T. Amat, T. Vazquez, Comportamiento de morteros de cementos alcalinos reforzados con fibras acrílicas $y$ de polipropileno., Mater. Construcción. 50, 2000, 69-84. http://materconstrucc.revistas.csic.es. recursos.biblioteca.upc.edu/index.php/materconstrucc/article/view/400/446.
[20] S.J.B.J. Lataste, T. Parry, S.G. Millard, M.N. Soutsos, Assessment of fibre orientation in ultra high performance fibre reinforced concrete and its effect on flexural strength, Mater. Struct. (2010) 1009-1023, https://doi.org/10.1617/ s11527-009-9562-3.

[21] M. del Río Merino, J. Santa Cruz Astorqui, M. González Cortina, Morteros aligerados con arcilla expandida: influencia de la granulometría y la adicciôn de fibras de vidrio AR en el comportamiento mecánico, Inf. La Construcción. 57 (2005) $39-46$

[22] M.L. Sánchez Paradela, A. Del Águíla, El envejecimiento de las pastas de cemento reforzadas con fibras de vidrio, Inf. La Construcción. 42 (1992) 65-71.

[23] W.T. Lin, A. Cheng, R. Huang, Y.C. Wu, T.Y. Han, Rock wool wastes as a supplementary cementitious material replacement in cement-based composites, Comput. Concr. 11 (2013) 93-104, https://doi.org/ 10.12989/cac.2013.11.2.093.

[24] W.T. Lin, A. Cheng, R. Huang, S.Y. Zou, Improved microstructure of cementbased composites through the addition of rock wool particles, Mater. Charact. 84 (2013) 1-9, https://doi.org/10.1016/j.matchar.2013.06.020.

[25] M.L. Sánchez Paradela, V. Sánchez Gálvez, Comportamiento a Tracción De Cementos Reforzados Con Fibras De Vidrio, Cons. Super. Investig. Científicas. 43 (1991) 13.

[26] B. Mobasher, S.P. Shah, Test parameters for evaluating toughness of glass-fiber reinforced concrete panels, ACI Mater. J. 86 (1989)

[27] H. Kim, G. Kim, J. Nam, J. Kim, S. Han, S. Lee, Static mechanical properties and impact resistance of amorphous metallic fiber-reinforced concrete, Compos. Struct. $134 \quad$ (2015) 831-844, https://doi.org/10.1016/ j.compstruct 2015.08 .128 .

[28] G. Melián, G. Barluenga, Aumento de la tenacidad de hormigones autocompactables reforzados con fibras cortas de polipropileno Toughness increase of self compacting concrete reinforced with polypropylene short fibers, Mater. Construcción. 60 (2010) 83-97, https://doi.org/10.3989/ mc. 2010.52309 .

[29] Q. Xiaochun, L. Xiaoming, C. Xiaopei, The applicability of alkaline-resistant glass fiber in cement mortar of road pavement: Corrosion mechanism and performance analysis, Int. J. Pavement Res. Technol. 10 (2017) 536-544, https://doi.org/10.1016/j.jiprt.2017.06.003.

[30] H. Du, K.H. Tan, X. Zhou, J.R. Slater, S.E. Wavell, O. Oladiran, H. Du, K.H. Tan, Waste glass powder as cement replacement in concrete concretes waste glass powder as cement replacement in concrete, Adv. Concr. Technol. 12 (2014) 468-477, https://doi.org/10.3151/jact.12.468.

[31] Z. Ge, R. Sun, K. Zhang, Z. Gao, P. Li, Physical and mechanical properties of mortar using waste Polyethylene Terephthalate bottles, Constr. Build. Mater 44 (2013) 81-86, https://doi.org/10.1016/j.conbuildmat.2013.02.073.

[32] S. Romaniega Piñeiro, Refuerzo de escayola mediante fibras de lana mineral procedentes del reciclaje de RCD, 2016.

[33] O. Väntsi, T. Kärki, Utilization of recycled mineral wool as filler in woodpolypropylene composites, Constr. Build. Mater. 55 (2014) 220-226, https:// doi.org/10.1016/j.conbuildmat.2014.01.050.

[34] A. Cheng, W.T. Lin, R. Huang, Application of rock wool waste in cement-based composites, Mater. Des. 32 (2011) 636-642, https://doi.org/10.1016 j.matdes.2010.08.014.

[35] A.N. Paredes, Trabajo final de Master: Estudio de la aplicabilidad de materiales compuestos en la edificación, 2016.

[36] C. Piña, E. Atanes, R. Merino, C. Viñas, A. Vidales, Feasibility of the use of mineral wool fibres recovered from CDW for the reinforcement of conglomerates by study of their porosity, Constr. Build. Mater. 191 (2018) 460-468, https://doi.org/10.1016/j.conbuildmat.2018.10.026.

[37] X. Zhou, F. Zheng, H. Li, C. Lu, An environment-friendly thermal insulation material from cotton stalk fibers, Energy Build. 42 (2010) 1070-1074, https:// doi.org/10.1016/j.enbuild.2010.01.020.

[38] J. Ramis, J. Alba, R. Rey, E. Escuder, V.J. Sanchís, Nuevos materiales absorbentes acústicos basados en fibra de kenaf New absorbent material acoustic based on kenaf s fibre, Mater. Construcción. 60 (2010) 133-143, https://doi.org/ $10.3989 / \mathrm{mc} .2010 .50809$.

[39] A. Yurdakul, E. Dolekcekic, G. Gunkaya, T. Kavas, B. Karasu, The usage of newly developed glass fibre in cement structure and their characterization, Constr. Build. Mater. $170 \quad$ (2018) 13-19, https://doi.org/10.1016/ j.conbuildmat.2018.03.062.

[40] M. Kosior-Kazberuk, J. Krassowska, A. Vidales Barriguete, C. Piña Ramirez, Fracture parameters of basalt fiber reinforced, An. Edif. 4 (2018) 52-58, https://doi.org/10.20868/ade.2018.3800. 